\title{
Structure and genetic variability in Nellore (Bos indicus) cattle by pedigree analysis
}

\author{
Pedro Alejandro Vozzi ${ }^{1}$, Cíntia Righetti Marcondes ${ }^{2}$, Cláudio de Ulhôa Magnabosco ${ }^{3}$, Luiz Antonio \\ Framartino Bezerra ${ }^{1}$ and Raysildo Barbosa Lôbo ${ }^{1}$ \\ ${ }^{1}$ Departamento de Genética, Faculdade de Medicina de Ribeirão Preto, Universidade de São Paulo, \\ Ribeirão Preto, SP, Brazil. \\ ${ }^{2}$ Universidade Federal do Tocantins, Porto Nacional, TO, Brazil. \\ ${ }^{3}$ Embrapa Cerrados, Planaltina, DF, Brazil.
}

\begin{abstract}
Parameters based on the probability of gene origin were used to describe the genetic variability in strains of Nellore and polled Nellore (Bos indicus) cattle that participated in the Program for Genetic Improvement of the Nellore Breed (Programa de Melhoramento Genético da Raça Nelore). The effective number of founders was 87.2 for Nellore and 107.9 for polled Nellore, while the number of ancestors was 59.8 for Nellore and 61.5 for polled Nellore and the remaining genomes were 39.4 for Nellore and 34.5 for polled Nellore cattle. The results indicate an intense use (by artificial insemination) of some sires and the absence of subdivisions in the population. The family structure in the two breeds was mainly caused by the genetic contribution of the same sires and only mating preferences for descendants of some founders are recorded in either breed. The results suggest that genetic variability needs monitoring in order to avoid the compromise of genetic improvement in economically important traits in the breeding program.
\end{abstract}

Key words: genetic drift, genetic variability matings, Nellore, pedigree analysis, probability of gene origin.

Received: March 22, 2005; Accepted: October 23, 2005.

\section{Introduction}

Pedigree information has recently been used to describe the genetic variability in bovine populations, the methods proposed by MacCluer et al. (1986), Lacy (1989) and Boichard et al. (1997) having been successfully applied in the analysis of genetic variability for the following cattle breeds: Abondance, Normanda and Limousin (Boichard et al. 1997); Simental, Braunviech, Pinzgauer and Grauvieh (Sölkner et al. 1998); Chianina, Maremmana and Mucca Pisana (Perez Torrezillas et al. 2002); and for the Spanish Alistana, Asturiana de la Montana, Asturiana de los Valles, Bruna dels Pirineus, Morucha, Pirenaica and Sayaguesa breeds (Gutierrez et al. 2003). The same type of analysis was used in the study of the genetic variability of Brazilian Zebu (Bos indicus) breeds (FJC Faria, 2002).

The parameters derived from the probability of gene origin are the effective number of founders $\left(N_{f}\right)$, the effective number of ancestors $\left(N_{a}\right)$ and the number of remaining genomes $\left(N_{g}\right)$. In this context 'founder' refers to an animal

Send correspondence to Pedro Alejandro Vozzi. Departamento de Genética, Faculdade de Medicina de Ribeirão Preto, Universidade de São Paulo, Av. Bandeirantes 3900, 14049-900 Ribeirão Preto, SP, Brazil. E-mail: pavozzi@genbov.fmrp.usp.br. whose genealogy is unknown. These descriptors represent a simple but precise procedure to describe genetic variability after a small number of generations, whereas the inbreeding coefficient and the effective population size are useful in monitoring the genetic variability over longer periods of time (Boichard et al. 1997).

Brazilian Nellore (B. indicus) germplasm mainly consists of animals imported into Brazil between 1920 and 1963 from India, where they are called Ongole. According to Magnabosco et al. (1997), six imported (IMP) sires (Golias $_{\text {imp }}$, Godhavari $_{\text {imp }}$, Karvadi imp, Kurupathy $_{\text {imp }}$, Mahal $_{\text {imp }}$, Taj $_{\text {imp }}$ and Rastã ${ }_{\text {imp }}$ ) have contributed significantly to the formation of the Brazilian Nellore herd, with nearly $20 \%$ of the genes present in the current herd having come from these six bulls, which are regarded as the genetic base of the Nellore breed in Brazil. It is estimated that the number of imported sires was not higher than 7,000. The breed showed outstanding adaptation to local environmental conditions, which caused significant population growth especially after the last importation in 1963. In 2003 the number of Nellore and polled Nellore with a definitive genealogy registry exceeded 2,820,000 animals, representing $87 \%$ of Zebu registries in Brazil (Associação Brasileira dos Criadores de Zebu; http://www.abcz.org.br/site/tecnica/ 
estatisticas/estat1.htm). The breed's herdBook has been kept since 1939.

The considerable increase in kinship between the main sires in the number of endogamous animals born recently (P.A.Vozzi, 2004), and the drop in variability detected by parameters based on the probability of gene origin (FJC Faria, 2002), may be related to different factors such as the prohibition on importation of sires, semen and embryos after 1963, the high genetic contribution of a few sires, the use of reproductive biotechnology and the statistical methods used for estimating genetic parameters and breeding values.

The aim of the study described in this paper was the evaluation of the genetic variability of the Nellore and polled Nellore strains that participate in the Program for Genetic Improvement of the Nellore Breed using parameters based on the probability of gene origin, and to determine the genetic contribution of different founder sires and the family structure of both strains.

\section{Materials and Methods}

The structure and genetic variability of Nellore and polled Nellore strain cattle was determined by pedigree analysis. The reference base population used in the study was a herd of 62,241 Nellore and 24,681 polled Nellore cattle born between 2000 and 2001 that participate in the Program for Genetic Improvement of the Nellore Breed, PMGRN (Lôbo et al. 2005). The genealogy registry for the reference population consisted of 399,253 pedigree record for the Nellore strain and 316,836 for the polled strain.

To describe the genetic variability in both strains we used parameters based on the probability of gene origin. These parameters were the effective number of founders $\left(N_{f}\right)$, the effective number of ancestors $\left(N_{a}\right)$ and the number of remaining genomes $\left(N_{g}\right)$. In this context 'founder' refers to an animal whose genealogy is unknown.

The effective number of founders $\left(N_{f}\right)$ represents the number of equally contributing founder animals that would produce the same genetic variability found in the investigated population, $N_{f}$ being calculated as $N_{f}=1 / \Sigma\left(p^{2}{ }_{i}\right)$ where $p_{i}$ is the ratio of alleles in the reference population contributed by founder $i$. When each founder has the same expected contribution to the population $N_{f}$ is equal to the number of founders $\left(N_{f u n}\right)$. In selection programs, the genetic contribution of founders is generally unbalanced because $N_{f}$ is considerably lower than $N_{f u n}$.
The effective number of ancestors $\left(N_{a}\right)$ determines the minimum number of ancestors (founders or not) required to explain the complete genetic diversity in the reference population and is obtained by computing the marginal contribution of each ancestor (Boichard et al. 1997) as $1 / \Sigma\left(p^{2}{ }_{k}\right)$ where $p^{2}{ }_{k}$ is the marginal contribution of ancestor $k$ in the population. An ancestor may not be a founder animal, although it may share genes with other ancestors, and the expected contribution in the population $q_{k}$ may be redundant and add up to more than one. As a result, only the marginal contribution of the ancestor under investigation can be used to assess the contribution of an ancestor's allele in the reference population.

The number of remaining genomes $\left(N_{g}\right)$ represents the number of founders with the same contribution that would lead to the same genetic diversity found in the population and would not cause loss of alleles due to genetic drift. We computed $N_{g}$ as $1 / \Sigma\left(p^{2}{ }_{i} / r_{i}\right)$ where $r_{i}$ is the expected ratio of alleles from founder $i$ that would remain in the reference population and $p_{i}$ is the expected ratio of alleles from founder $i$ that contributed to the reference population. A total of 1,000 segregations were simulated for the calculation of $N_{g}$ in both strains.

The marginal contribution of the main founders and ancestors was used in order to determine the family structure of both strains. The kinship coefficient and parameters $N_{f}, N_{a}$ and $N_{g}$ were estimated by using the PEDIG software (http://dga.jouy.inra.fr/sgqa/diffusions.htm).

\section{Results}

The parameters based on the probability of gene origin resulting from the pedigree analysis for the Nellore and polled Nellore strains are shown in Table 1, from which it can be seen that although the variability in Nellore has a larger number of founder animals in pedigree the genetic contribution of some sires was higher in comparison to the polled strain. In the Nellore strain, 87 founders would represent the genetic variability in animals born between 2000 and 2001. In the polled Nellore strain, the genes of 107.9 founder sires would be represented in animals born in the same time period. The $N_{a}$ value for both strains indicated that approximately 60 ancestors (founders or not) contributed with $100 \%$ of the alleles. The $N_{g}$ value was lower for the polled strain, indicating the higher kinship present in this strain.

The genetic contribution of the main ancestor and of the 50 main ancestors in both strains is shown in Table 2.

Table 1 - Genetic variability in Nellore and polled Nellore strains after pedigree analysis.

\begin{tabular}{lccccc}
\hline Strain & $\begin{array}{c}\text { Number of founders } \\
\left(N_{\text {fun }}\right)\end{array}$ & $\begin{array}{c}\text { Effective number of } \\
\text { founders }\left(N_{f}\right)\end{array}$ & $\begin{array}{c}\text { Effective number of } \\
\text { ancestors }\left(N_{a}\right)\end{array}$ & $\begin{array}{c}\text { Number of remaining } \\
\text { genomes }\left(N_{g}\right)\end{array}$ & $\begin{array}{c}\text { Relationship } \\
\text { coefficient }(R)\end{array}$ \\
\hline Nellore & 37,481 & 87.2 & 59.8 & 39.4 & 2.6 \\
Nellore Polled & 13,705 & 107.9 & 61.5 & 34.5 & 3.0 \\
\hline
\end{tabular}


Few ancestries have elevated genetic contribution in either strain. The $32.2 \%$ of the genetic variability seen in the Nellore strain is explainable by the marginal contribution of the ten main ancestries, while in the polled Nellore strain $37.4 \%$ of the variability is due to the genetic contribution of the same number of ancestries.

Tables 3 and 4 show the marginal contributions of the main founder sires and their descendants in both strains. The Karvadi ${ }_{i m p}$ ancestor was identified as the sire with the highest marginal contribution in both Nellore (Table 3 ) and polled Nellore (Table 4) strains. The genetic contribution of the main ancestor and his descendants was approximately $25 \%$ of genes in both strains. A similar genetic contribution was recorded for the Taj Mahal $_{\text {imp }}$, Kurupathy ${ }_{\text {imp }}$ and Golias $_{\text {imp }}$ ancestors in both strains despite the smaller magnitude when compared with the contribution of the main founder. In the Nellore strain (Table 3), six founder sires and their main descendants had a genetic contribution of $35 \%$. In the polled Nellore strain (Table 4), seven families of sires apportioned nearly $37 \%$ of the genes. A differential genetic contribution was detected in the polled strain for Godhavari $_{\text {imp }}$, Rolex ${ }_{\text {imp }}$ and Nagpur imp $_{\text {founders with } 12.2 \%}$ of the genes present in the strain. Even though the contribution of the Godhavari $i_{\text {imp }}$ founder was less than $0.2 \%$ their main descendants had the second highest marginal contribution detected among polled Nellore, with almost $6.1 \%$ of the genes present in the animals born between 2000 and 2001.

\section{Discussion}

Table 2 - Genetic contribution of the principal ancestries in each strain.

\begin{tabular}{lcc}
\hline Number of ancestries & Nellore (\%) & Polled Nellore (\%) \\
\hline Principal ancestry & 8.7 & 6.9 \\
Five principal ancestries & 24.0 & 24.2 \\
Ten principal ancestries & 32.2 & 37.4 \\
Twenty principal ancestries & 39.3 & 44.9 \\
Fifty principal ancestries & 47.3 & 54.9 \\
\hline
\end{tabular}

Table 3 - Genetic contributions of the principal founders and the principal descendants in the Nellore strain.

\begin{tabular}{lcc}
\hline Name of founder & $\begin{array}{c}\text { Marginal contribution } \\
(\%)\end{array}$ & $\begin{array}{c}\text { Marginal contribution } \\
\text { of the family }(\%)^{*}\end{array}$ \\
\hline Karvadi $_{\text {imp }}$ & 8.7 & 24.5 \\
Godhavari $_{\text {imp }}$ & 0.7 & $<1.0$ \\
Taj Mahal $_{\text {imp }}$ & 0.6 & 6.0 \\
Chekurupadu $_{\text {imp }}$ & 0.4 & $<1.0$ \\
Kurupathy $_{\text {imp }}$ & 0.3 & 1.7 \\
Golias $_{\text {imp }}$ & 0.3 & 1.0 \\
Other founders & $<0.1$ & $\cong 65.0$ \\
\hline
\end{tabular}

*Approximate family contribution.
Table 4 - Genetic contributions of the principal founders and the principal descendants in the polled Nellore strain.

\begin{tabular}{lcc}
\hline Name of founder & $\begin{array}{c}\text { Marginal contribution } \\
(\%)\end{array}$ & $\begin{array}{c}\text { Marginal contribution } \\
\text { of the family }(\%)^{*}\end{array}$ \\
\hline Karvadi $_{\text {imp }}$ & 6.9 & 23.0 \\
Taj Mahal $_{\text {imp }}$ & 0.8 & 4.0 \\
Kurupathy $_{\text {imp }}$ & 0.5 & $<0.1$ \\
Rolex $_{\text {imp }}$ & 0.5 & 3.7 \\
Golias $_{\text {imp }}$ & $<0.2$ & 1.0 \\
Godhavari $_{\text {imp }}$ & $<0.2$ & 6.1 \\
Nagpur $_{\text {imp }}$ & $<0.2$ & 2.4 \\
Other founder & $<0.1$ & $\cong 63.0$ \\
\hline
\end{tabular}

*Approximate family contribution.

The results of the pedigree analysis reveal the intense participation of few families in reproduction and show the non-existence of a subdivision in the population due to the intense use of reproductive biotechnologies and the high genetic contribution of some sires.

The diversity values resulting from the parameters based on the probability of gene origin in both strains were smaller than those found in the Italian Chianina and Maremmana breeds (Perez Torrecillas et al. 2002). Similar results were obtained with polled Nellore (Faria et al. 2002) and the Simental breed (Sölkner et al.1998).

Although both strains represent the largest herd sizes for Zebu breeds in Brazil, the significant number of reproductive females and the large number of sires located in artificial insemination centers (http://www.asbia.org.br/ mercado/relat05.asp) act as if they were small population where a few sires that are progressively more related take part in the reproduction. The use of intense artificial insemination as a reproductive method and the lack of subdivisions in the population may also be explained by the marginal contribution of the main sires in each strain (Table 2). Boichard et al. (1997) noted the same trend in breeds where the use of artificial insemination prevails over natural mating (Normanda and Abondance). The $N_{a}$ value may be considered low in both strains if the population size for the breed and the number of animals registered each year are taken into account. The $N_{g}$ value and the kinship coefficient for both strains indicate that the selection effect and genetic drift were higher for the polled Nellore strain, possibly because of linebreeding to fix the polled trait in the population (Tables 1 and 2). The 50 main ancestors have contributed $47.3 \%$ of genes to the Nellore strain whereas in the polled strain they contributed $54.9 \%$, reinforcing the hypothesis of linebreeding to fix the polled trait. The important contribution of the Godhavari $i_{\text {imp }}$, Rolex $x_{\text {imp }}$ and Nagpur $_{\text {imp }}$ founders is possibly due to the fact that some descendants of such sires were intensely used in the formation of the polled Nellore herd. 
Because of the use of reproductive biotechnologies such as artificial insemination and in vitro fertilization in the Nellore breed, the genes of founder animals have been segregated in both strains. Individually, only some of the founders descendants were significantly used in the formation of either strain.

The fact that the founder herd for the breed was formed by a small number of sires, the prohibition on the imports of original genetic resources since 1962 and the preference for the use of certain sires can certainly explain the present degree of variability in the Nellore breed participant of the breeding program.

In conclusion, the results obtained in this study using the parameters based on the probability of gene origin demonstrate that the Nellore breed participant of the breeding program have lower levels of genetic variability than the other breeds of smaller population sizes cited in this study. Since the same founder animals are responsible for the germplasm in both strains the intense use of few families of sires, artificial insemination and other reproductive biotechnologies have led to reduced genetic differences both within and between strains and it thus seems that genetic variability control should be implemented in both strains in order to avoid future gene losses that may affect economically important traits.

\section{Acknowledgments}

Thanks go to the Brazilian agencies CAPES, PRONEX, FAEPA, FAPESP and ANCP

\section{References}

Boichard D, Maignel L and Verrier E (1997) The value of using probabilities of gene origin to measure genetics variability in a population. Genet Sel Evol 29:5-23.

Faria FJC, Vercesi Filho AE, Madalena FE and Josahkian LA (2002) Estrutura populacional da raça Nelore Mocho. Arq Bras Med Vet Zootec 54:501-509.

Gutierrez JP, Altibarra J, Días C, Quintanilla R, Cañon J and Piedrafita J (2003) Pedigree analysis of eight Spanish beef cattle breeds. Genet Sel Evol 35:46-63.

Lacy RC (1989) Analysis of founder representation in pedigrees: Founder equivalents and founder genome equivalents. Zool Biol 8:111-123.

Lôbo RB, Bezerra LAF, Oliveira HN, Magnabosco CU, Zambianchi AR, Albuquerque LG, Bergmann JAG and Sainz RD (2005) Avaliação genética de Touros e Matrizes da raça Nelore. Ribeirão Preto, Brazil. 128 pp.

MacCluer JW, Van Der Berg J, read B and Ryder OA (1986) Pedigree analysis by computer simulation. Zool Biol 5:147-160.

Magnabosco CU, Cordeiro CMT, Trovo JBF, Mariante AS, Lôbo RB and Josahkian LA (1997) Catálogo de linhagens do germoplasma zebuíno: Raça Nelore. Embrapa-Cenargen, Documentos, 23, $52 \mathrm{pp}$

Perez Torrecillas C, Bozzi R, Negrini R, Filippini F and Georgetti A (2002) Genetic variability of three Italian cattle breeds determined by parameters based on probabilities of gene origin. J Anim Breed Genet 119:274-279.

Sölkner J, Filipcic L and Hampshire N (1998) Genetic variability of populations and similarity of subpopulations in Austrian cattle breeds determined by analysis of pedigrees. Anim Sci 67:249-256

Associate Editor: Pedro Franklin Barbosa 